\title{
Postharvest Ripening and Quality of Guatemalan-West Indian Avocado Hybrids under Simulated Commercial Shipping Temperatures Following Treatment with Aqueous 1-Methylcyclopropene
}

\author{
Adrian D. Berry ${ }^{1}$, Steven A. Sargent ${ }^{1,3}$, \\ Marcio Eduardo Canto Pereira ${ }^{2}$, and Donald J. Huber ${ }^{1}$
}

\begin{abstract}
Additional Index wORDs. Persea americana, ethylene, firmness, marketability, commercial handling

Summary. Two Guatemalan-West Indian avocado (Persea americana) hybrids ('Monroe' and 'Booth 8') were treated with an aqueous formulation of 1-methylcyclopropene (1-MCP) to determine effects on ripening and quality during storage simulating commercial shipping temperatures. Fruit harvested at preclimacteric stage were immersed in aqueous $1-M C P$ at $75 \mu \mathrm{g} \cdot \mathrm{L}^{-1}\left(1.39 \mathrm{mmol} \cdot \mathrm{m}^{-3}\right)$ or in deionized water for 1 minute, stored at $10^{\circ} \mathrm{C}$ for 14 days, and then transferred to $20{ }^{\circ} \mathrm{C}$ until ripe. Respiration rate, ethylene production, softening, and change in epidermal hue* angle were delayed and/or suppressed in both cultivars exposed to 1-MCP, although effects were less pronounced with Booth 8 . Hue* angles for 1MCP-treated 'Monroe' fruit had the highest values (darkest green peel color) of all treatments at full-ripe stage (hue* angle $=117$ ). For control and treated 'Monroe' fruit respiration peaked on days 15 and 21, while ethylene production from both treatments peaked on day 16. Respiration and ethylene production peaked on day 16 for both control and 1-MCP-treated 'Booth 8' fruit. Fruit treated with 1-MCP consistently showed diminished respiration and ethylene peaks. Days to full-ripe stage were unaffected by treatment. 'Booth 8' fruit from both treatments were considered ripe ( $15 \mathrm{~N}$ whole fruit firmness) after 17 days; however, only $8 \%$ of control fruit were marketable, whereas $58 \%$ of 1 -MCP-treated fruit were marketable, based on subjective appearance ratings using the Jenkins-Wehner score. The development of peel blemishes during storage was the primary cause of unmarketable fruit. 'Monroe' control and 1-MCP-treated fruit were soft after about 22 days and were significantly more marketable (control 70\% and 1-MCP 85\%). Avocados treated with 1-MCP ripened over a longer period than control fruit but maintained a higher percentage of marketable fruit.
\end{abstract}

$\mathrm{H}$ ybrid avocado cultivars of Indian and West IndianGuatemalan origin are the main types grown in tropical production areas around the world. More than 60 cultivars are grown in southern Florida, permitting an extended harvest season from May to early March (Crane et al., 2007). Since $\approx 80 \%$ of the fruit is shipped outside the state, quality maintenance over extended periods is critical to growers and shippers (Bronson, 2009; Evans and Nalampang, 2006).

Avocados typically ripen within a few days of harvest (Seymour and Tucker, 1993); however, fruit can be

${ }^{1}$ Horticultural Sciences Department, Institute of Food and Agricultural Science, University of Florida, P.O. Box 110690, Gainesville, FL 32611

${ }^{2}$ Embrapa Mandioca e Fruticultura, Rua Embrapa, s/n, Caixa Postal 7, Cruz das Almas, BA, 44480-000, Brazil

${ }^{3}$ Corresponding author. E-mail: sasa@ufl.edu. stored for 10 to $21 \mathrm{~d}$ at 4 to $13{ }^{\circ} \mathrm{C}$, depending on cultivar (Woolf et al., 2004). West Indian and GuatemalanWest Indian avocado hybrids are more temperature sensitive than Guatemalan and Mexican types and are prone to develop chilling injury when stored below $13{ }^{\circ} \mathrm{C}$, depending upon the cultivar (Campbell and Hatton,
1959). A limiting factor of storing avocados for extended periods is the expression of internal pulp discoloration, a chilling injury symptom that can develop during poor temperature management or ethylene exposure (Chaplin et al., 1983; Pesis et al., 2002). Other reports have noted that application of the inhibitor of ethylene perception, l-MCP (Sisler, 2006; Sisler et al., 2003) reduced the expression of certain physiological disorders during storage such as flesh discoloration, stringy vascular tissue, and decays for numerous crops (Blankenship and Dole, 2003; Huber, 2008), including 'Hass' avocado, a Guatemalan type cultivar (Adkins et al., 2005; Woolf et al., 2005).

Gaseous 1-MCP is commercially applied to fruit held in sealed containers or rooms over periods up to $24 \mathrm{~h}$; however, an aqueous formulation of 1-MCP available for preharvest application shows promise for postharvest application. Choi et al. (2008) demonstrated that a 1 -min immersion in a solution of $1-M C P$ at $625 \mu \mathrm{g} \cdot \mathrm{L}^{-1}$ suppressed 'Hass' avocado ripening comparable to a 9 -h exposure to gaseous $1-\mathrm{MCP}$ at $500 \mathrm{~nL} \cdot \mathrm{L}^{-1}$. Aqueous 1-MCP treatments at 1.39 and $2.77 \mu \mathrm{mol} \cdot \mathrm{L}^{-1}$ delayed ripening of 'Simmonds' by $33 \%$ and $67 \%$, 'Booth 7' by $40 \%$ and $80 \%$, and 'Monroe' by $50 \%$ and $83 \%$ (Pereira et al., 2013b). Issues of concern regarding commercial postharvest use of aqueous 1-MCP include the necessity for uniform coverage of the targeted commodity, the compatibility of aqueous 1-MCP with other postharvest treatments and potential volatilization into the surrounding area causing loss of aqueous 1-MCP efficacy or unintended exposure of other crops (Choi et al., 2008). Published studies have focused on avocado ripening under ideal ripening conditions

\begin{tabular}{llll}
\hline $\begin{array}{l}\text { Units } \\
\begin{array}{l}\text { To convert U.S. to SI, } \\
\text { multiply by }\end{array}\end{array}$ & U.S. unit & SI unit & $\begin{array}{l}\text { To convert SI to U.S., } \\
\text { multiply by }\end{array}$ \\
\hline 29.5735 & $\mathrm{fl} \mathrm{oz}$ & $\mathrm{mL}$ & 0.0338 \\
3.7854 & $\mathrm{gal}$ & $\mathrm{L}$ & 0.2642 \\
25.4 & inch(es) & $\mathrm{mm}$ & 0.0394 \\
0.0044 & $\mathrm{lbf}$ & $\mathrm{kN}$ & 224.8089 \\
4.4482 & $\mathrm{lbf}$ & $\mathrm{N}$ & 0.2248 \\
28.3495 & $\mathrm{oz}$ & $\mathrm{g}$ & 0.0353 \\
1 & $\mathrm{ppb}$ & $\mu \mathrm{g} \cdot \mathrm{kg}^{-1}$ & 1 \\
1 & $\mathrm{ppb}$ & $\mu \mathrm{g} \cdot \mathrm{L}^{-1}$ & 1 \\
1 & $\mathrm{ppm}$ & $\mu \mathrm{L} \cdot \mathrm{kg}^{-1}$ & 1 \\
$\left({ }^{\circ} \mathrm{F}-32\right) \div 1.8$ & ${ }^{\circ} \mathrm{F}$ & ${ }^{\circ} \mathrm{C}$ & $\left({ }^{\circ} \mathrm{C} \times 1.8\right)+32$
\end{tabular}


$\left(20^{\circ} \mathrm{C}\right)$. However, typical transit shipping temperatures for GuatemalanWest Indian avocado hybrids range from 10 to $13{ }^{\circ} \mathrm{C}$, depending on the cultivar and shipping distance; however, upon receiving at distribution centers, they are normally held at room temperature $\left(20\right.$ to $\left.22^{\circ} \mathrm{C}\right)$.

The objective of this study was to examine the potential of using an aqueous formulation of $1-\mathrm{MCP}$ to delay fruit ripening of two GuatemalanWest Indian avocado hybrids under a simulated commercial handling scenario.

\section{Materials and methods}

Plant material. Two lateseason avocado cultivars, Monroe and Booth 8 were harvested at preclimacteric stage according to the 2009-10 shipping schedule regulated by the Florida Avocado Administrative Committee (FAAC). The FAAC annually establishes four harvest dates (labeled A, B, C, D) for each cultivar based on minimum fruit size and weight (FAAC, 2014). The largest fruit are harvested at Harvest Date $\mathrm{A}$, and the minimum required fruit size/weight decreases with successive Harvest Dates B, C, and D. 'Monroe' fruit were harvested on 18 Nov. 2009 (Harvest Date A) and 'Booth 8' on 7 Jan. 2010 (Harvest Date D) from commercial groves in Miami-Dade County, FL. On the day of harvest, fruit were transported at $22{ }^{\circ} \mathrm{C}$ to the Postharvest Horticulture Laboratory, (Horticultural Sciences Department, University of Florida, Gainesville). Following overnight storage at $20{ }^{\circ} \mathrm{C}$, sound fruit of uniform size (average weight of $853 \mathrm{~g}$ for 'Monroe' and $445 \mathrm{~g}$ for 'Booth 8 ') were selected for treatment.

AQueous 1-MCP PReParation, TREATMENT, AND STORAGE. Fruit were placed in mesh bags ('Booth 8': $\mathrm{n}=$ 24; 'Monroe': $\mathrm{n}=20$ per treatment), then immersed in aqueous 1-MCP (prepared from AFXRD-038 powder, $3.8 \%$ a.i.; AgroFresh, Rohm and Haas, Philadelphia, PA) at $75 \mu \mathrm{g} \cdot \mathrm{L}^{-1}$ $\left(1.39 \mathrm{mmol} \cdot \mathrm{m}^{-3}\right)$ or in deionized water (control) at $20{ }^{\circ} \mathrm{C}$ for $1 \mathrm{~min}$, according to (Choi et al., 2008). Following treatments, fruit were dried with paper towels and packed in single-layer, commercial shipping cartons. Fruit were stored at $10{ }^{\circ} \mathrm{C}$ ( $85 \%$ to $90 \%$ relative humidity) for $14 \mathrm{~d}$ to simulate commercial shipping conditions, then transferred to $20^{\circ} \mathrm{C}$ for ripening.

Fruit Quality assessments. During storage, whole fruit firmness, subjective quality ratings, external color, ethylene production, respiration rate, and weight loss were measured at 2- to 3-d intervals. Nondestructive compression tests were performed on whole, unpeeled fruit ('Booth 8': $\mathrm{n}=$ 24; 'Monroe': $\mathrm{n}=20$ per treatment) using a Universal Testing Instrument (model 4411; Instron, Canton, MA) fitted with a flat-plate probe $(5 \mathrm{~cm}$ diameter) and $0.5-\mathrm{kN}$ load cell. The probe was driven with a crosshead speed of $20 \mathrm{~mm} \cdot \mathrm{min}^{-1}$ and the force was recorded at $2.5 \mathrm{~mm}$ deformation on opposite sides of the equatorial region of each fruit. Maximum force generated during probe travel was used for firmness values. Avocados were considered full-ripe when whole fruit firmness decreased to $15 \mathrm{~N}$, the point at which the fruit was considered too soft for commercial handling (Jeong et al., 2002).

During storage, avocado marketability was evaluated based on peel blemishes. Surface area affected by blemishes was estimated using the Jenkins-Wehner score, where: $0=$ $0 \%, \mathrm{l}=0 \%$ to $3 \%, 2=3 \%$ to $6 \%, 3=$ $6 \%$ to $12 \%, 4=12 \%$ to $25 \%, 5=25 \%$ to $50 \%, 6=50 \%$ to $75 \%, 7=75 \%$ to $87 \%$, and $8=87 \%$ to $100 \%$ (Jenkins and Wehner, 1983). A score of 3 was considered to be the limit of marketability based on the U.S. Department of Agriculture (USDA) avocado grade standards that limit appearance defects to $10 \%$ of the fruit surface (USDA, 1957). Percent marketable fruit were calculated from the number of fruit that softened to full-ripe stage $(\leq 15 \mathrm{~N})$ with a Jenkins-Wehner score of $\leq 3$.

Peel color at the equatorial region was monitored during storage by reflectance colorimetry (hue* angle) with a chroma meter (model CR400; Konica Minolta, Tokyo, Japan) operating with a $C$ illuminant and 11-mm diameter aperture according to McGuire (1992). When possible, peel blemishes were avoided during color readings. A hue* angle of $180^{\circ}$ represents green and $90^{\circ}$ represents yellow.

Respiration rate and ethylene production were measured daily on fruit held at $10^{\circ} \mathrm{C}$ for $14 \mathrm{~d}$, then transferred to $20^{\circ} \mathrm{C}$ until ripe. Avocado fruit were individually placed in 2 - $\mathrm{L}$ plastic containers $(\mathrm{n}=4$ per treatment $)$ fitted with septa and sealed for 60 or $20 \mathrm{~min}$ while stored at 10 or $20^{\circ} \mathrm{C}$, respectively. A 5-mL headspace sample was withdrawn and analyzed as described in detail by Zhang et al. (2011). Individual fruit weights were tracked throughout storage and percent weight loss was calculated and reported on fresh weight basis.

Avocados remained in storage, regardless of peel appearance, and the above mentioned parameters were measured until fruit firmness reached $15 \mathrm{~N}$ or at the first signs of decay at which time they were removed from storage.

Statistical analysis. The experiment was conducted in a completely randomized design. Data were analyzed using SAS (version 9.1.3, SAS Institute, Cary, NC). Significant differences between means were separated using Duncan's multiple range test $(P \leq 0.05)$.

\section{Results and discussion}

At harvest, initial firmness values were 250 and $192 \mathrm{~N}$ for 'Monroe' and 'Booth 8' fruit, respectively (Fig. 1). During storage at $10^{\circ} \mathrm{C}, 4 \%$ of 'Booth $8^{\prime}$ control fruit softened and reached full-ripe stage (the $15-\mathrm{N}$ limit for whole fruit firmness) by day 12 . However, after $14 \mathrm{~d}$ at $10^{\circ} \mathrm{C}$, there were no differences in firmness due to treatment: 'Monroe' fruit remained relatively firm $(130 \mathrm{~N})$, while 'Booth 8' fruit were significantly softer $(37 \mathrm{~N})$ (Fig. 1). Following transfer to $20^{\circ} \mathrm{C}$, there was no effect of $1-\mathrm{MCP}$ on 'Booth 8 ', where the majority of fruit from both treatments ripened by day 17. 'Monroe' fruit for both treatments ripened after $20 \mathrm{~d}$ (control) and $23 \mathrm{~d}$ (1-MCP); however, these ripening periods were not significantly different due to fruitto-fruit variability. Control 'Monroe' fruit ripened within a $3-\mathrm{d}$ period (19 to $21 \mathrm{~d}$ ), whereas 1 -MCP-treated fruit ripened over an extended 8 -d period (from 19 to $27 \mathrm{~d}$ ).

In previous studies by Pereira et al. (2013b), 'Monroe' avocados were treated in the same manner with aqueous 1-MCP, but under continuous storage at $20^{\circ} \mathrm{C}$; these fruit ripened in 12 and $18 \mathrm{~d}$ for control- and l-MCPtreated fruit, respectively. The authors also reported that avocado ripening rate was cultivar-dependent; the early season cultivar Simmonds (West Indian type) responded to 1-MCP, but softened at an accelerated rate compared with lateseason cultivar Monroe ( 6 and $10 \mathrm{~d}$ for 
control and treated fruit, respectively). Similar responses were reported for another early-to-midseason cultivar, Beta (Guatemalan-West Indian type), that softened in 8 (control) and $14 \mathrm{~d}$ (1-MCP-treated) at $20{ }^{\circ} \mathrm{C}$ (Pereira et al., 2013a). Ripening asynchrony in individual fruit was reported for 1-MCP-treated avocados (Pereira, 2010); however, in the present tests, fruit from both cultivars ripened uniformly, possibly due to application of lower 1-MCP concentrations than those used by Pereira (2010).

Based on the $\mathrm{L}^{*}$ data $\left(\mathrm{L}^{*} 0=\right.$ black and $100=$ white), peel blemishes did not affect peel color determinations, combined mean $L^{*}$ values (control and 1-MCP-treated fruit) during storage ranged from 38.96 to 46.75 for 'Monroe' and from 38.12 to 40.27 for 'Booth 8' (data not shown). Initial peel color was similar for both cultivars (hue ${ }^{*}$ angle $=121^{\circ}$ to $124^{\circ}$ ); during storage at $10^{\circ} \mathrm{C}$, Monroe fruit remained slightly darker green than Booth 8 fruit (Fig. 2). Following transfer to $20{ }^{\circ} \mathrm{C}$, hue * angles for control 'Monroe' fruit were higher (darker green) than 'Booth 8' fruit on day 18 ; 1-MCPtreated 'Monroe' fruit had the highest values of all treatments when ripe (hue* angle $=117$ ). This effect of 1 MCP in delaying the breakdown of chlorophyll was also observed with several Guatemalan-West Indian avocado cultivars that were treated with either gaseous (Jeong et al., 2002) or aqueous 1-MCP (Pereira et al., 2014).

During storage at $10{ }^{\circ} \mathrm{C}$, the respiration rate and ethylene production remained at basal levels for 'Monroe' fruit. After transfer to $20^{\circ} \mathrm{C}$, respiration peaked on days 15 and 21 for control and 1-MCP-treated 'Monroe' fruit, respectively, although the latter peak was attenuated by $40 \%$ relative to the control (Fig. 3A). Ethylene production for 'Monroe' fruit from both treatments peaked $2 \mathrm{~d}$ after transfer to $20^{\circ} \mathrm{C}$ (day 16) (Fig. 3B). By contrast, respiration and ethylene production for 'Booth 8' fruit began to increase during storage at $10^{\circ} \mathrm{C}$. By day 9 , the respiration rate of control 'Booth 8' was about twice that of 1 MCP-treated fruit, and this trend continued following transfer to $20^{\circ} \mathrm{C}$ and subsequent ripening (Fig. 3A). The onset of the ethylene climacteric in 'Booth 8' preceded that of respiration,

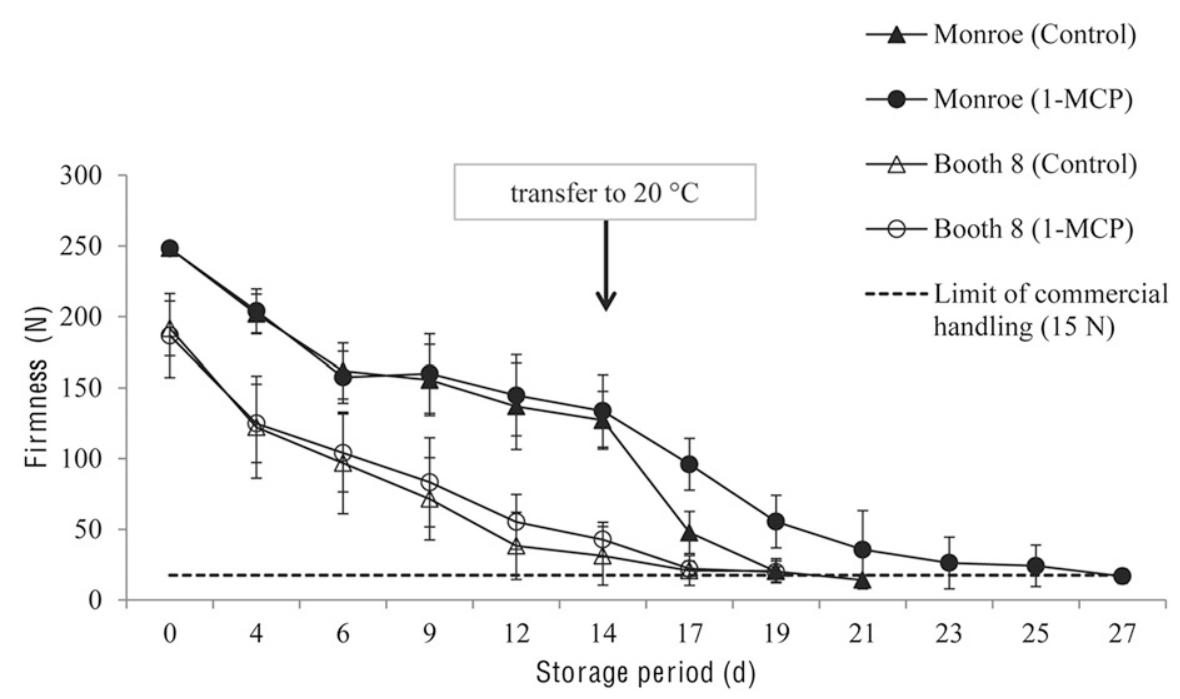

Fig. 1. Whole fruit firmness of 'Monroe' and 'Booth 8' avocado untreated or treated with $75 \mu \mathrm{g} \cdot \mathrm{L}^{-1}$ (ppb) aqueous 1 -methycyclopropene (1-MCP) during storage at $10{ }^{\circ} \mathrm{C}\left(50.0^{\circ} \mathrm{F}\right)$ for $14 \mathrm{~d}$ and transfer to $20^{\circ} \mathrm{C}\left(68.0{ }^{\circ} \mathrm{F}\right)$ until ripe. Vertical bars represent SD; $1 \mathrm{~N}=\mathbf{0 . 2 2 4 8}$ lbf.

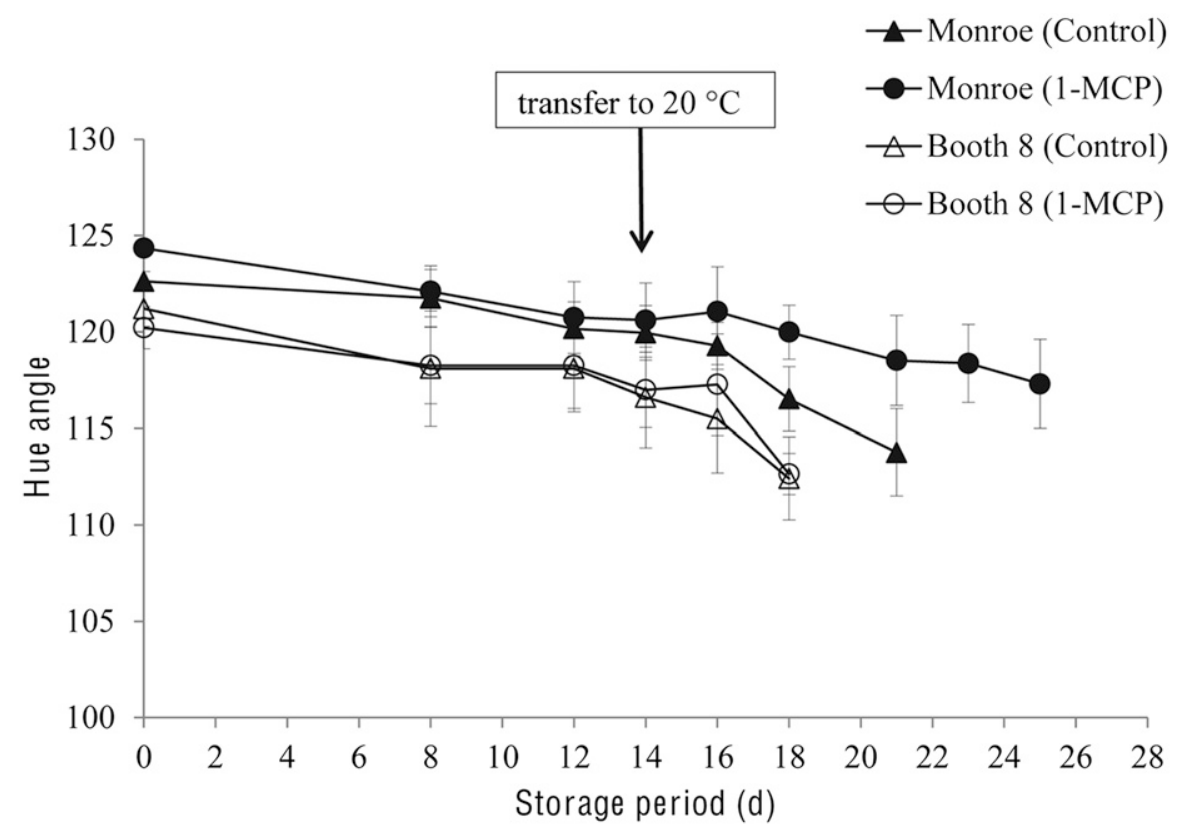

Fig. 2. External hue* angle values for 'Monroe' and 'Booth 8' avocado untreated or treated with $75 \mu \mathrm{g} \cdot \mathrm{L}^{-1}(\mathrm{ppb})$ aqueous 1 -methycyclopropene (1-MCP) during storage at $10^{\circ} \mathrm{C}\left(50.0^{\circ} \mathrm{F}\right)$ for $14 \mathrm{~d}$ and transfer to $20^{\circ} \mathrm{C}\left(68.0^{\circ} \mathrm{F}\right)$ until ripe. Vertical bars represent SD $(n=4)$.

beginning by day 6 at $10^{\circ} \mathrm{C}$ (Fig. 3B). Both respiration and ethylene production peaked on day 16; maxima for 1MCP-treated fruit were attenuated.

Control and 1-MCP-treated 'Booth 8' fruit were ripe after $17 \mathrm{~d}$; only $8 \%$ of control fruit were marketable, whereas $58 \%$ of 1 -MCP-treated fruit were marketable, a 7 -fold increase (Table 1). At full-ripe stage, there were significantly more marketable 'Monroe' avocados $(70 \%$ to $85 \%$ ) than 'Booth 8 ' avocados (Table 1). Some fruit from both cultivars never softened to full-ripe stage: more 'Booth 8 ' fruit remained unripe $($ control $=33 \%, 1-\mathrm{MCP}=$ 17\%) compared with 'Monroe' fruit (control $=0 \%$ and $\mathrm{MCP}=10 \%)$ (data not shown). Peel blemishes were the principal reason that fruit from both cultivars were rated unmarketable 
(A)

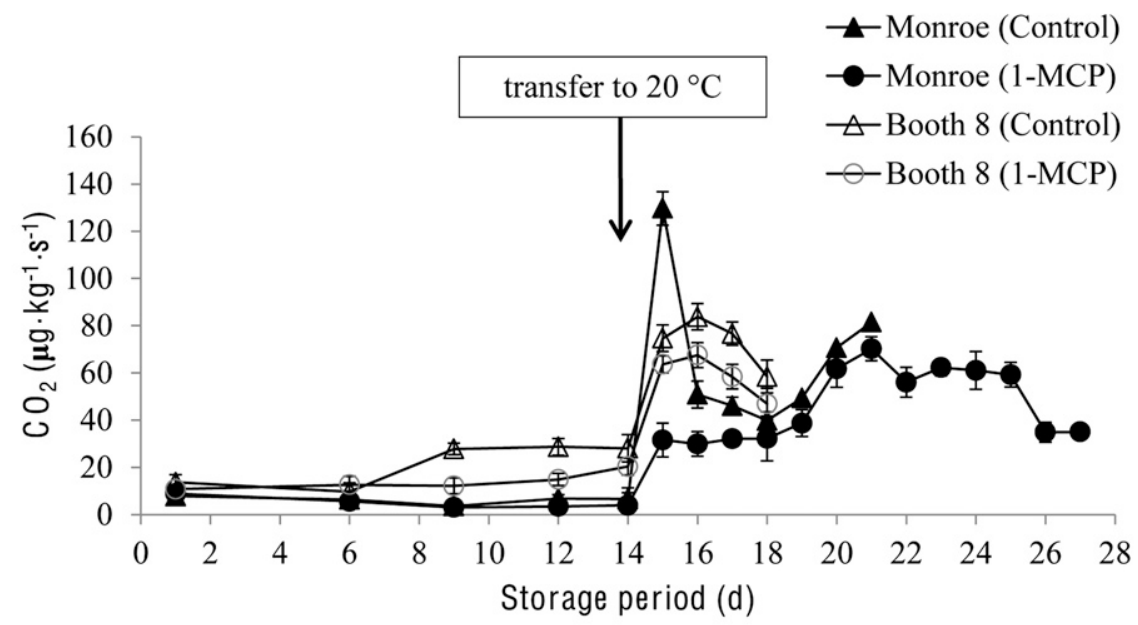

(B)

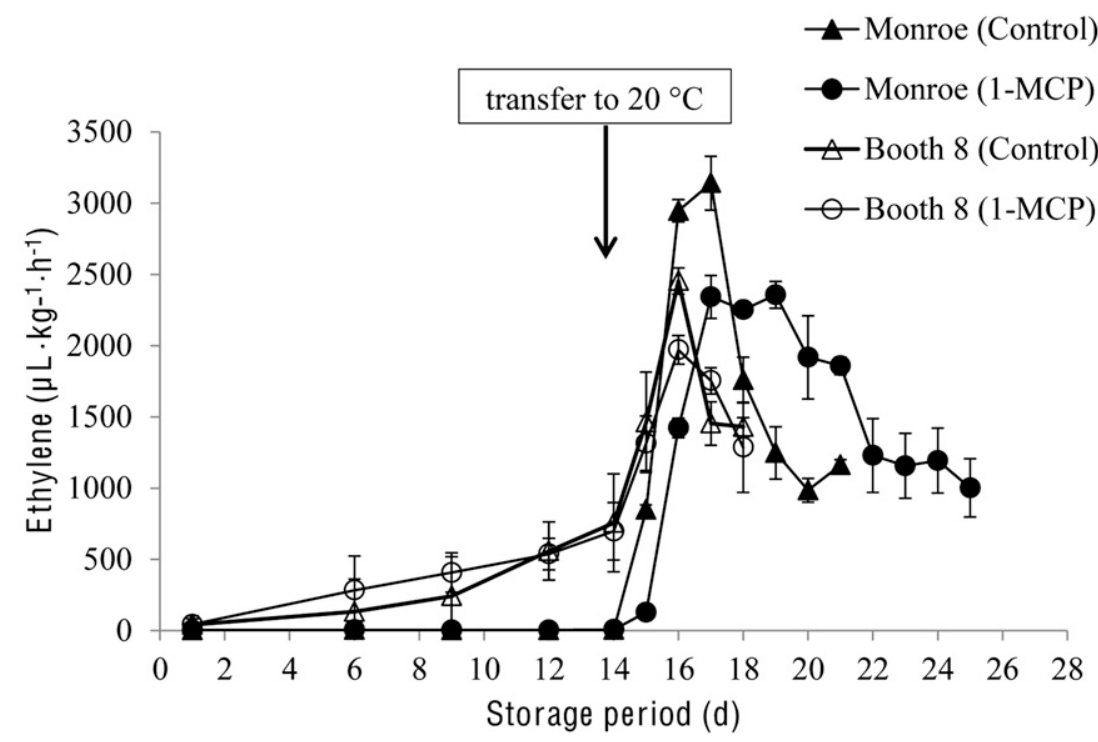

Fig. 3. Avocado respiration $\left[\mathrm{CO}_{2}(\mathrm{~A})\right]$ and ethylene (B) rates for 'Monroe' and 'Booth 8' avocado untreated or treated with $75 \mu \mathrm{g} \cdot \mathrm{L}^{-1}(\mathrm{ppb})$ aqueous 1 methycyclopropene (1-MCP) during storage at $10^{\circ} \mathrm{C}\left(50.0^{\circ} \mathrm{F}\right)$ for $14 \mathrm{~d}$ and transfer to $20^{\circ} \mathrm{C}\left(68.0^{\circ} \mathrm{F}\right)$ until ripe. Vertical bars represent SD $(\mathrm{n}=4) ; 1 \mu \mathrm{g} \cdot \mathrm{kg}^{-1}=1$ $\mathrm{ppb}, \mathrm{l} \mu \mathrm{L} \cdot \mathrm{kg}^{-1}=1 \mathrm{ppm}$. treated and control, respectively, putatively identified as anthracnose (data not shown).

In this study, both cultivars lost $6 \%$ to $8 \%$ weight during storage; Monroe fruit lost more weight than Booth 8 , likely due to longer storage/ ripening times (Table 1 ). These findings are similar to those reported by Jeong et al. (2002), where control and gaseous 1-MCP-treated avocado fruit displayed $6 \%$ to $7 \%$ weight loss during 12 -d storage at $20{ }^{\circ} \mathrm{C}$. However, despite similar weight loss in this study, no stem-end shriveling was observed, consistent with a report by Pereira et al. (2013a).

Avocado is unique among climacteric fruits in that ripening initiates only following detachment from the tree. Gazit and Blumenfeld (1970) reported that 'Hass' avocado did not uniformly respond to ethylene exposure until $2 \mathrm{~d}$ postharvest. The minimal response of 'Booth 8' to 1-MCP in this study was most likely due to the extremely late harvest date (7 Jan. 2010). Harvest date D (the latest date for commercial harvest) began on 26 Oct. for 'Booth 8', more than 2 months earlier than the actual harvest date. Avocados harvested late in the season have an inherently shorter delay to the initiation of ripening, and hence lower sensitivity to 1-MCP (Huber, 2008). Woolf et al. (2004) noted that, with increasing delay to harvest, avocados required less exposure time to ethylene to initiate ripening and were more tolerant of lower storage temperatures. Respiration rate and ethylene production for 'Booth 8' fruit supported the effect of the late harvest, where ripening in both control and 1-MCPtreated fruit initiated after only $6 \mathrm{~d}$ at

Table 1. Effect of 1-methycyclopropene (1-MCP) on ripening, marketability, and weight loss of 'Monroe' and 'Booth 8' avocados during $27 \mathrm{~d}$ storage $\left[14 \mathrm{~d}\right.$ at $10^{\circ} \mathrm{C}\left(50.0^{\circ} \mathrm{F}\right)$ plus $13 \mathrm{~d}$ at $\left.20^{\circ} \mathrm{C}\left(68.0{ }^{\circ} \mathrm{F}\right)\right]$.

\begin{tabular}{|c|c|c|c|c|c|c|}
\hline \multirow[b]{3}{*}{ Cultivar } & \multicolumn{2}{|c|}{ Ripening period $(d)^{z}$} & \multirow{2}{*}{\multicolumn{2}{|c|}{$\begin{array}{c}\text { Marketable fruit }(\%)^{y} \\
(\text { mean } \pm \text { SD })\end{array}$}} & \multirow{2}{*}{\multicolumn{2}{|c|}{ Wt loss (\%) }} \\
\hline & & & & & & \\
\hline & Control & 1-MCP & Control & 1-MCP & Control & 1-MCP \\
\hline Booth 8 & $17 \pm 1.74$ & $17 \pm 1.45$ & $8 \pm 2.41$ & $58 \pm 11.80$ & $5.92 \pm 1.05$ & $6.09 \pm 1.14$ \\
\hline
\end{tabular}

${ }^{2}$ Full-ripe stage was determined from the average days for the majority of fruit to soften to $15 \mathrm{~N}(3.4 \mathrm{lbf})$.

yercent marketable fruit were calculated from the number of ripe fruit with Jenkins-Wehner Score of $\leq 3$ (Jenkins and Wehner, 1983 ). Unripe fruit after $27 \mathrm{~d}$ of storage were not included.

(Jenkins-Wehner score $>3 \%$, or $>12 \%$ surface affected) and developed primarily following transfer to $20{ }^{\circ} \mathrm{C}$.
There was no obvious decay on 'Monroe' fruit; however, 'Booth 8 ' fruit showed $4 \%$ and $8 \%$ decay on $1-\mathrm{MCP}$ -
$10{ }^{\circ} \mathrm{C}$ (Fig. 2). By contrast, early harvested 'Monroe' fruit (Harvest Date A, before 23 Nov.) remained 
preclimacteric during $14 \mathrm{~d}$ storage at $10{ }^{\circ} \mathrm{C}$, possibly due to low sensitivity to $1-\mathrm{MCP}$.

In this study, Guatemalan-West Indian type avocados treated with aqueous 1 -MCP $\left(75 \mu \mathrm{g} \cdot \mathrm{L}^{-1}\right.$ for $1 \mathrm{~min})$ maintained better appearance during ripening under commercial conditions than untreated fruit. However, harvest maturity had a greater effect on the onset of ripening than treatment with 1-MCP. Determination of the full commercial potential of 1-MCP to delay ripening in these avocado hybrids will require further study of 1-MCP concentration, formulation (gaseous vs. aqueous), and exposure time for each cultivar and harvest date.

\section{Literature cited}

Adkins, M.F., P.J. Hofman, B.A. Stubbings, and A.J. Macnish. 2005. Manipulating avocado fruit ripening with l-methylcyclopropene. Postharvest Biol. Technol. 35:33-42.

Blankenship, S.M. and J.M. Dole. 2003. 1-Methylcyclopropene: A review. Postharvest Biol. Technol. 28:1-25.

Bronson, C.H. 2009. Florida agriculture statistical directory. 19 May 2010. <http://www.florida-agriculture.com/ consumers/facts.htm>.

Campbell, C.W. and T.T. Hatton, Jr. 1959. Chilling injury in pollock avocados during cold storage. Proc. Florida State Hort. Soc. 72:337-338.

Chaplin, G.R., R.B.H. Wills, and D. Graham. 1983. Induction of chilling injury in stored avocados with exogenous ethylene. HortScience 18:952-953.

Choi, S.T., P. Tsouvaltzis, C.I. Lim, and D.J. Huber. 2008. Suppression of ripening and induction of asynchronous ripening in tomato and avocado fruits subjected to complete or partial exposure to aqueous solutions of 1-methylcyclopropene. Postharvest Biol. Technol. 48:206214.

Crane, J.H., E. Evans, and C. Balerdi. 2007. A review of the Florida avocado industry. 21 Mar. 2012. <http://www. avocadosource.com/WAC6/en/ Extenso/5a-209.pdf>.
Evans, E. and S. Nalampang. 2006. World, U.S. and Florida avocado situation and outlook. Univ. Florida, Florida Coop. Ext. Serv., Inst. Food Agr. Sci. FE639. 19 May 2010. <http://edis.ifas.ufl.edu/ FE639>.

Florida Avocado Administrative Committee. 2014. Avocado shipping schedule for the 2009-2010 crop year. Florida Avocado Administrative Committee, Homestead, FL.

Gazit, S. and A. Blumenfeld. 1970. Response of mature avocado fruits to ethylene treatments before and after harvest. J. Amer. Soc. Hort. Sci. 95:229-231.

Huber, D.J. 2008. Suppression of ethylene responses through application of 1 methylcyclopropene: A powerful tool for elucidating ripening and senescence mechanisms in climacteric and nonclimacteric fruits and vegetables. HortScience 43:106-111.

Jenkins, S.F. and T.C. Wehner. 1983. A system for the measurement of foliar diseases of cucumber. Cucurbit Genet. Coop. Rpt. 6:10-12.

Jeong, J., D.J. Huber, and S.A. Sargent. 2002 . Influence of 1 -methylcyclopropene (1-MCP) on ripening and cell wall matrix polysaccharides of avocado (Persea americana) fruit. Postharvest Biol. Technol. 25:241-256.

McGuire, R.G. 1992. Reporting of objective color measurements. HortScience 27:1254-1255.

Pereira, M.E.C. 2010. Ripening, volatiles and sensory attributes of West Indian and Guatemalan-West Indian hybrid avocados as affected by l-methycyclopropene and ethylene. Univ. Florida, Gainesville, PhD Diss.

Pereira, M.E.C., S.A. Sargent, C.A. Sims, D.J. Huber, J.H. Crane, and J.K. Brecht. 2014. Ripening and sensory analysis of Guatemalan-West Indian hybrid avocado following ethylene pretreatment and/or exposure to gaseous or aqueous 1-methylcyclopropene. Postharvest Biol. Technol. 92:121-127.

Pereira, M.E.C., S.A. Sargent, C.A. Sims, D.J. Huber, C.L. Moretti, and J.H. Crane. 2013a. Aqueous 1-MCP extends longevity and does not affect sensory acceptability of Guatemalan-West
Indian hybrid avocado. HortTechnology $23: 468-473$

Pereira, M.E.C., D.M. Tieman, S.A. Sargent, H.J. Klee, and D.J. Huber. $2013 \mathrm{~b}$. Volatile profiles of ripening West Indian and Guatemalan-West Indian avocado cultivars as affected by aqueous 1-methylcyclopropene. Postharvest Biol. Technol. 80:37-46.

Pesis, E., M. Ackerman, R. Ben-Arie, O. Feygenberg, X. Feng, A. Apelbaum, R. Goren, and D. Prusky. 2002. Ethylene involvement in chilling injury symptoms of avocado during cold storage. Postharvest Biol. Technol. 24:171181.

Seymour, G.B. and G.A. Tucker. 1993. Avocado, p. 53-81. In: G.B. Seymour, J. Taylor, and G.A. Tucker (eds.). Biochemistry of fruit ripening. Chapman \& Hall, London, UK.

Sisler, E.C. 2006. The discovery and development of compounds counteracting ethylene at the receptor level. Biotechnol. Adv. 24:357-367.

Sisler, E.C., T. Alwan, R. Goren, M. Serek, and A. Apelbaum. 2003. 1-Substituted cyclopropenes: Effective blocking agents for ethylene action in plants. Plant Growth Regulat 40:223-228.

U.S. Department of Agriculture. 1957. United States standards for grades of Florida avocados. U.S. Dept. Agr., Washington, DC.

Woolf, A.B., C. Requejo-Tapia, K. Cox, R. Jackman, A. Gunson, M. Arpaia, and A. White. 2005. 1-MCP reduces physiological storage disorders of 'Hass' avocados. Postharvest Biol. Technol. 35:43-60.

Woolf, A.B., A. White, M.L. Arpaia, and K.C. Gross. 2004. Avocado. In: K.C. Gross, Wang, C.Y. and M. Saltveit (eds.). The commercial storage of fruits, vegetables, and florist and nursery stocks. U.S. Dept. Agr., Agr. Res. Serv., Hndbk. 66. 19 May 2010. <http://www.ba.ars. usda.gov/hb66/034avocado.pdf>.

Zhang, Z., D.J. Huber, and J. Rao. 2011. Ripening delay of mid-climacteric avocado fruit in response to elevated doses of 1-methylcyclopropene and hypoxiamediated reduction in internal ethylene concentration. Postharvest Biol. Technol. 60:83-91. 